\title{
Desain Game Edukasi Ilmu Tajwid Bagi Anak Usia Dini menggunakan Pemodelan Finite State Automata
}

\author{
Yanto $^{* 1}$, Dinar Ismunandar ${ }^{2}$, Erni $^{3}$, Santoso Setiawan ${ }^{4}$, Muhammad Ifan Rifani Ihsan \\ 1,2,3,4,5 Program Studi Ilmu Komputer, Universitas Nusa Mandiri \\ email: 14002423@nusamandiri.ac.id*1,14002421@nusamandiri.ac.id ${ }^{2}$, \\ 14002422@nusamandiri.ac.id ${ }^{3}$, santoso.sts@nusamandiri.ac.id ${ }^{4}$,ifan.mii@nusamandiri.ac.id ${ }^{5}$
}

(Received: 16 April 2021/ Accepted: 5 Juni 2021 / Published Online: 20 Juni 2021)

\begin{abstract}
Abstrak
Penelitian ini membahas bagaimana Finite State Automata (FSA) dapat dijadikan pemodelan untuk mendesain suatu aplikasi game Ilmu Tajwid sebagai diagram bisnis. Penelitian ini bertujuan untuk mempermudah anak usia dini dalam belajar ilmu tajwid dengan mengelompokkan huruf hijaiyah kedalam pengelompokkan ilmu tajwid dengan menggunakan sentuhan tangan. Jenis teori automata yang digunakan adalah non-deterministic finite automata dengan transisi epsilon (E) atau yang lebih dikenal sebagai E-NFA. Tiap transisi, input, state yang ada dari NFA, pada dasarnya untuk menunjukkan karakteristik atau keadaan-keadaan yang terjadi pada sebuah aplikasi game. Pentingnya penelitian ini, selain untuk pembelajaran ilmu tajwid dari usia dini adalah untuk menunjukkan bahwa teori automata dapat digunakan untuk membantu mendesain suatu sistem dalam pembuatan aplikasi game. Hasil dari desain aplikasi game Ilmu Tajwid ini merupakan tampilan secara kasar karena masih akan ada tahapan pengembangan selanjutnya dan dapat meyakinkan bahwa aplikasi game dapat dibangun dari pemodelan E-NFA.
\end{abstract}

Kata kunci: Aplikasi Game, Ilmu Tajwid, E-NFA.

\begin{abstract}
This study discusses how Finite State Automata (FSA) can be used as a model to design a Tajweed Science game application as a business diagram. This study aims to facilitate early childhood in learning the science of recitation by grouping hijaiyah letters into grouping the science of recitation by using a touch of the hand. The type of automata theory used is a non-deterministic finite automata with epsilon transition $(E)$ or better known as E-NFA. Each transition, input, state that exists from the NFA, is basically to show the characteristics or states that occur in a game application. The importance of this research, in addition to learning recitation from an early age, is to show that automata theory can be used to help design a system in making game applications. The results of this Tajweed Science game application design are a rough display because there will still be further development stages and can ensure that game applications can be built from E-NFA modeling.
\end{abstract}

Keywords: Game Application, Tajwid Science, E-NFA.

\section{PENDAHULUAN}

Membaca Al-Qur'an dengan baik dan benar merupakan salah satu ilmu yang sangat penting, yang harus dimiliki oleh umat muslim sejak usia dini sebagai dasar sebelum mempelajari ilmu-ilmu lainnya. Al-Qur'an yang berisikan 30 macam huruf hijaiyah dan firman Allah ini dijadikan pedoman hidup bagi kaum muslim di seluruh dunia, oleh karena itu ilmu tajwid sangat di perlukan untuk membaca Al-Qur'an dengan baik dan benar (Rizal, Bustami, \& Azzahra, 2019). Ilmu Tajwid adalah dasar untuk membaca Al-Quran yang baik dan benar, dan merupakan ilmu yang mempelajari tatacara pengucapan huruf-huruf yang terdapat dalam kitab suci Al-Qur'an (Maarif et al., 2018). Namun selama ini metode belajar mengajar ilmu tajwid di lingkungan Madrasah Diniyah Awaliyah (MDA) yang digunakan 
masih belum maksimal dan waktu belajar yang terbatas membuat siswa/i mudah jenuh untuk belajar (Hadi, Efendi, Danang, \& Wakid, 2017). Di dunia teknologi yang saat ini semakin maju, kita dapat memanfaatkan salah satu teknologi tersebut untuk sarana pembelajaran ilmu tajwid bagi siswa/i MDA. Untuk itu di penulis merancang salah satu metode pembelajaran yang dapat digunakan dengan maksimal dan waktu belajar yang tidak terbatas serta memanfaatkan teknologi masa kini. Yakni dengan pembuatan game edukasi yang bisa membuat siswa/i tidak mudah jenuh untuk belajar serta bisa belajar dimanapun dan kapanpun.

Pada saat ini game sudah tidak hanya digunakan untuk media hiburan saja, sekarang sudah banyak game yang dapat digunakan sebagai media pembelajaran atau yang disebut dengan game edukasi atau edugame (Arridho, 2017; Komarudin \& Yuniarti, 2016). Game edukasi merupakan suatu game komputer yang berisi materi pendidikan yang disajikan dalam bentuk permainan interaktif untuk melatih kreativitas dan meningkatkan kecerdasan siswa (Setiaji, 2017). Dalam game ini terdapat konten edukasi yang menarik untuk digunakan oleh anak usia dini salah satunya untuk pembelajaran tajwid al qur'an berbasis mobile game yang hanya mengaharuskan pemain mengelompokkan huruf hijaiyah ke dalam kelompok hukum tajwid yang benar. Anak-anak juga dan mendapatkan ilmu dan pengetahuan didalam game tersebut diantanya dalam game sejarah (Saputra, Haryanto, \& Dolphina, 2019) dan geme ilmu tajwid ini.

FSA merupakan salah satu pemodelan matematika dari seuatu sistem yang yang menerima masukan (input) dan keluaran (output) diskrit yang memiliki state yang berhingga dan dapat berpindah-pindah dari suatu state ke state yang lain serta tidak memiliki tempat penyimpanan dan hanya bisa mengingat state terkini (Fadhlurrahman \& Capah, 2020; Handayani, Ismunandar, Putri, \& Gata, 2020). Mustofa, Sidiq, \& Rahmawati (2018) menyatakan Finite Automata merupakan model yang baik untuk komputer dengan jumlah memori yang sangat kecil. Teori automata itu sendiri merupakan alat yang efektif untuk merancang, mengotomatisasi dan mengoptimalkan suatu sistem, dan di dalam teori automata ini terdapat dua jenis yaitu DFA dan NFA (Irawan, Siregar, Damanik, \& Saragih, 2020).

DFA dan NFA Merupakan mesin pada teori bahasa dan automata yang mudah untuk diaplikasikan dan sesuai dengan logika manusia. Pada DFA setiap simbol atau input hanya akan menuju ke satu state tertentu (Ardiansyah, Hardi, \& Gata, 2020), sedangkan pada NFA memungkinkan untuk satu input menimbulkan transisi ke lebih dari satu kondisi dan memungkinkan dapat memberikan beberapa gerakan sehingga keluarannya tidak dapat dipastikan (Sahrul, Muhazabah, Prasetyo, Yunita, \& Zahra, 2018; Wirasbawa, Benedict, Santoso, Farhan, \& Kusnadi, 2019).

Pada penelitian sebelumnya sudah ada beberapa penelitian game edukasi menggunakan pemodelan FSA diantaranya, game kebersihan lingkungan (Hutagaluh, 2017), dan mengenai game pilah sampah yang menggunakan pemodelan FSA yang bertujuan untuk menunjukkan bahwa teori automata dapat membantu untuk mendesain suatu permainan (Sahrul et al., 2018). Sementar itu, penelitian ini membahas mengenai desain aplikasi permainan Ilmu tajwid untuk meningkatkan daya minat anak-anak mempelajari ilmu tajwid yang memanfaatkan salah satu jenis teori finite state automata (FSA) yaitu non-deterministic finite automata (NFA) dengan menggunakan epsilon (E) atau E-NFA.

\section{METODE}

Pada penelitian ini terdiri dari 3 tahapan penelitian yakni: desain FSA, Perancangan system, dan desain game tajwid (lihat gambar 1). Berdasarkan gambar 1. Tahapan yang dilakukan yaitu penerapan teori automata pada penelitian ini yang merupakan jenis dari NFA, selanjutnya merancang sistem yang akan di terapkan pada desain aplikasi game tajwid 
kemudian yang terakhir yaitu membuat desain tampilan yang terdapat dalam game tajwid pada penelitian ini.

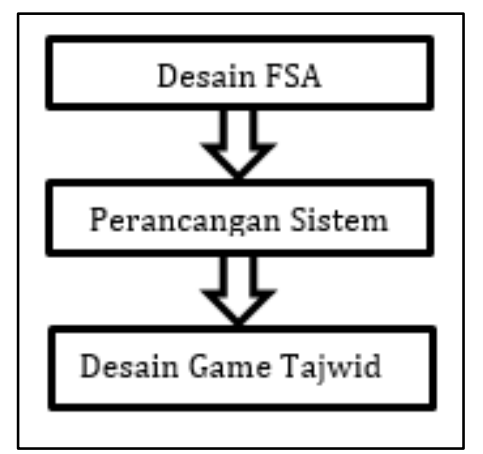

Gambar 1. Kerangka Konseptual

\section{HASIL DAN PEMBAHASAN}

\section{Hasil}

Perancangan Sistem

Untuk perancangan sistem, pada penelitian ini menggunakan unified modelling language (UM). Usecase Diagram menunjukkan interaksi antara Usecase dan actor (Kharmoum, Retal, Ziti, \& Omary, 2019; Muntohar, 2020; Sabirin, Sulistiyarini, \& Zulkarnain, 2020; Suprapto, Fauziah, Fitri, \& Hayati, 2020). Diagram ini menggambarkan model lengkap tentang apa saja yang dilakukan di dalam game tajwid, siapa yang berperan diluar dan di dalamnya. Pada gambar 2 menjelaskan interaksi antara pengguna dengan tampilan yang ada di game. Sementara itu, untuk use case diagram gam tajwid ini terdiri dari (1) Goal: Player dapat memulai game, melihat materi, tentang game, dan keluar dari game, (2) Pre-Conditions: Player dapat masuk kedalam menu utama game, (3) Post-Conditions: player melihat menu yang terdapat pada game, (4) Failed End Conditions: Player membatalkan bermain game. Untuk lebih jelasnya use case mengenai game tajwid ini, dapat dilihat pada tabel 1 .

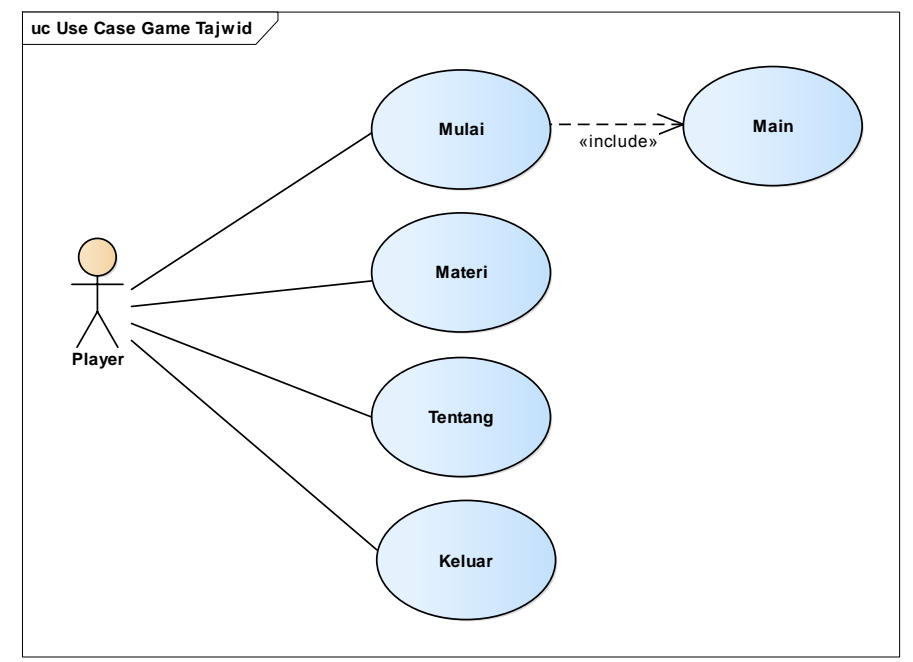

Gambar 2. Usecase Diagram Game Tajwid

Activity Diagram menggambarkan berbagai alir aktifitas yang terjadi dalam dalam sistem yang sedang dirancang, bagaimana masing-masing alir berawal, decision yang mungkin terjadi dan bagaimana mereka berakhir. Pada gambar 3 menjelaskan tentang aktifitas diagram yaitu memilih menu mulai kemudian memulai game selanjutnya 
menampilkan huruf beserta pengelompokkannya kemudian game memproses waktu berjalan untuk mengelompokkan huruf hijaiyah dan apabila jawaban benar maka akan menambahkan score dan kembali menampilkan huruf hijaiyah melanjutkan game kembali dan apabila jawaban salah maka akan mengurangi score dan kembali menampilkan huruf hijaiyah melanjutkan game.

Tabel 1. Deskripsi Usecase Diagram Game Tajwid

\begin{tabular}{|c|c|}
\hline Use case name & Game Tajwid \\
\hline Requrements & A1-A3 \\
\hline Goal & $\begin{array}{l}\text { Player dapat memulai game, melihat materi, tentang game, } \\
\text { dan keluar dari game }\end{array}$ \\
\hline $\begin{array}{l}\text { Pre-Conditions } \\
\text { Post-Conditions }\end{array}$ & $\begin{array}{l}\text { Player dapat masuk kedalam menu utama game } \\
\text { player melihat menu yang terdapat pada game }\end{array}$ \\
\hline Failed End Conditions & Player membatalkan bermain game \\
\hline Primary Actors & Player \\
\hline \multirow{4}{*}{ Main Flow/Basic Path } & 1. Player dapat memulai game \\
\hline & 2. Player dapat melihat materi \\
\hline & 3. Player dapat melihat tentang game \\
\hline & 4. Player dapat keluar dari game \\
\hline Invariant & - \\
\hline
\end{tabular}

Desain Game Tajwid

Berdasarkan dari penelitian yang sudah ada saya mendapat instirasi untuk mendesain aplikasi game tajwid yang menyesuaikan model NFA yang telah dibuat, Berikut merupakan gambar dari aplikasi permainan yang didesain. Pada gambar 4 dapat dilihat bahwa menu awal dari game yang dimana ketika player membuka aplikasi game tajwid ini.

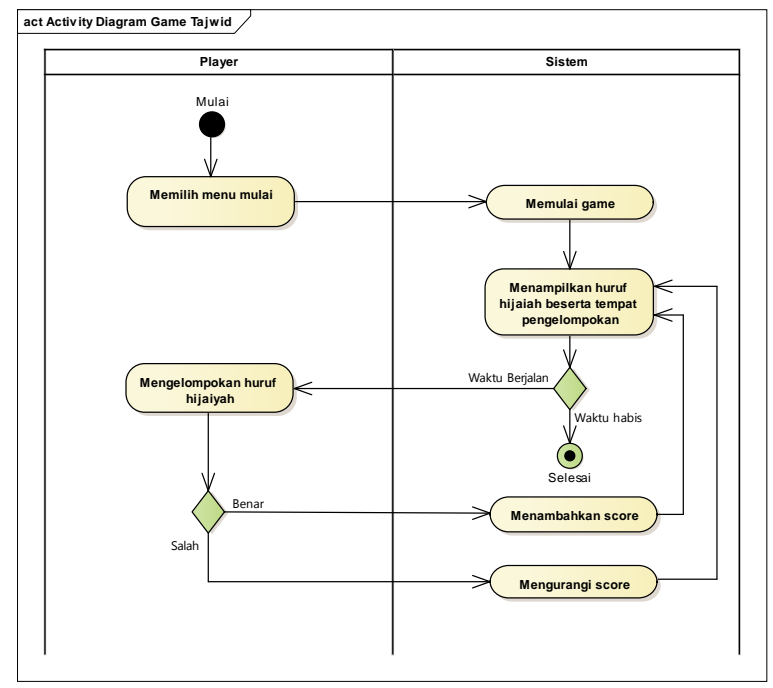

Gambar 3. Activity Diagram Game Tajwid

Pada Gambar 5 dapat dilihat bahwa keadaan awal mulai dari game yaitu akan ada huruf-huruf hijaiyah yang terdapat di paling bawah layar akan bergerak kearah samping, ini merupakan intial state Huruf Berjalan. Pada Gambar 6 Menunjukkan ketika player mengambil sebuah huruf hijaiyah den memindahkannya ke dalam sebuah kelompok tajwid. Ini merupakan salah satu input Huruf Dimasukkan yang akan mengantarkan pada state Pengecekan Huruf dari state Huruf Berjalan. 


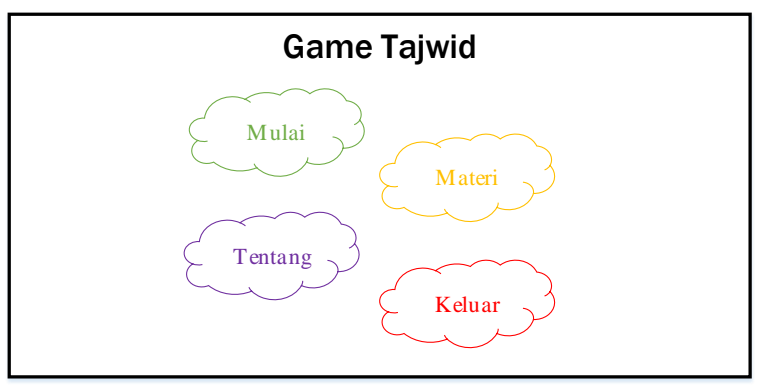

Gambar 4. Menu Awal

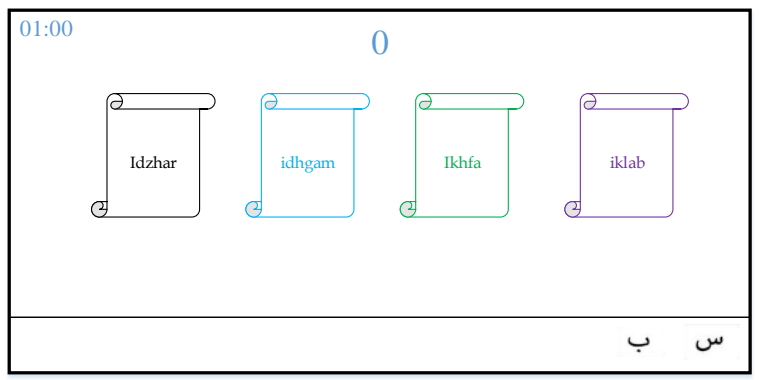

Gambar 5. Keadaan Awal Mulai

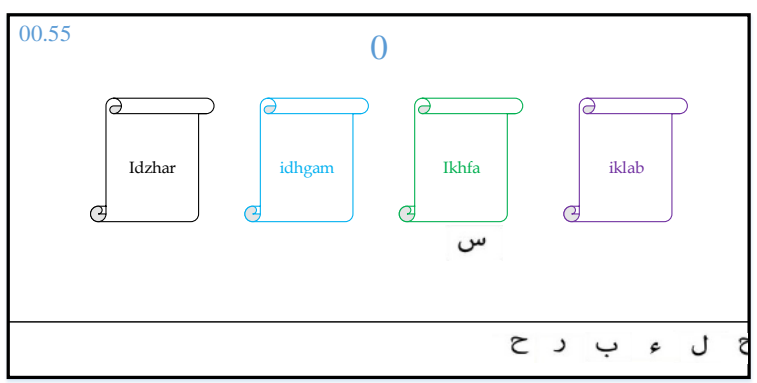

Gambar 6. Player Memindahkan Huruf

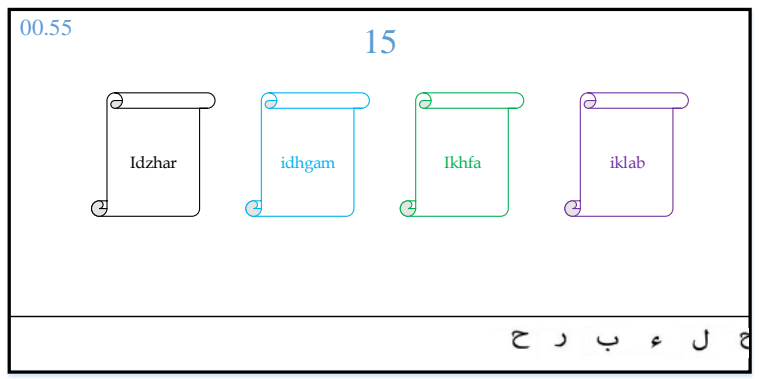

Gambar 7. Nilai Bertambah

Pada gambar 7 dapat dilihat bahwa nilai player akan bertambah, ini merupakan kondisi dimana sistem berada di keadaan Nilai Bertambah jika setelah Pengecekan Huruf player memasukkan huruf di dalam kelompok yang benar dan menjadikan input merupakan Kelompok Yang Benar. Sementara itu, pada gambar 8 dapat dilihat bahwa nilai player akan berkurang, ini merupakan kondisi dimana sistem berada di keadaan Nilai Berkurang jika setelah Pengecekan Huruf player memasukkan huruf di dalam kelompok yang salah dan menjadikan input merupakan Kelompok Yang Salah. 


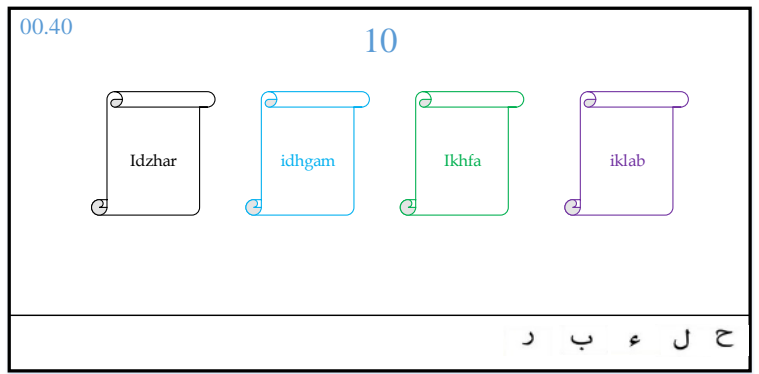

Gambar 8. Nilai Berkurang

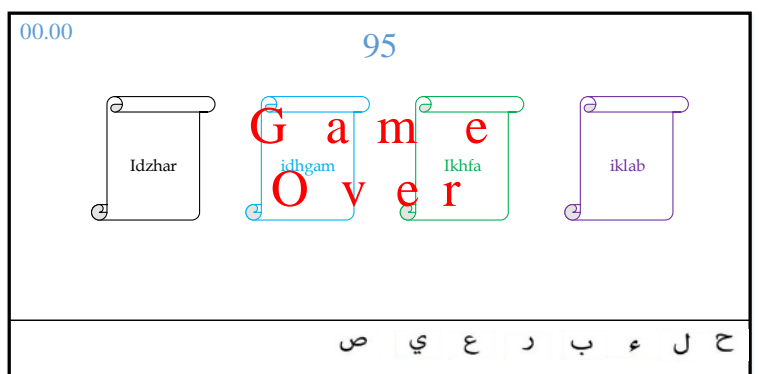

Gambar 9. Permainan Berakhir

Pada gambar 9 dapat dilihat bahwa permainan telah berakhir dikarenakan waktu yang telah habis, ini merupakan kondisi dimana sistem berada dikeaadan Waktu Habis/Permainan Selesai dan di keaan inilah fungsi epsilon (E) terlihat jelas dengan tanpa input kondisi dapat berubah menjadi state Waktu Habis/Permainan Selesai dari state Huruf Berjalan.

\section{Pembahasan}

\section{Finite State Automata}

Berikut pada tabel 2, merupakan beberapa penjelasan mengenai simbol pada FSA. Model yang digunakan dalam aplikasi pengelompokan huruf tajwid ini yaitu dengan menggunakan E-NFA. Berikut ini adalah desain NFA yang menjelaskan karakteristik dan kondisi-kondisi di dalam permainan pengelompkan huruf tajwid yang ditunjukkan pada gambar 10.

Tabel 2. Simbol Pada FSA

$\longrightarrow$ Final State

Pada gambar 10 adalah desain dari E-NFA pada game huruf tajwid. Hal tersebut didapat dijelaskan sebagai berikut:

\section{Himpunan State}

$\mathrm{Q}=\{$ Huruf berjalan, Pengecekakan huruf, Score bertambah, Score berkurang, Waktu habis $\}$

1. Huruf Berjalan: Pada state ini, berbagai huruf hijaiyah akan mulai muncul dan berjalan sampai huruf itu diambil dan dimasukkan ke salah satu kelompok hokum tajwid. Ketika suatu huruf pada state huruf berjalan dipilih maka didefinisikan sebagai inputan huruf dimasukkan dan akan melakukan transisi dari state huruf berjalan ke state pengecekkan huruf. 
2. Pengecekkan huruf: setelah memilih salah satu huruf hijaiyah dari state huruf berjalan, pemain akan memilih kelompok hukum tajwid yang sesuai dengan huruf tersebut. Ketika huruf yang dipilih dimasukkan kedalam kelompok yang benar, maka didefinisikan sebagai inputan huruf dimasukka kedalam kelompok yang benar dan akan melakukan transisi dari state pengecekkan huruf ke state nilai bertambah. Samahalnya dengan sebaliknya, ketika pemain menempatkan kedalam kelompok yang salah, maka akan didefinisikan sebagai inputan huruf dimasukkan kedalam kelompok yang salah dan akan melakukan transisi dari state pengecekkan huruf ke state nilai berkurang.

3. Nilai Bertambah: di state ini, setiap pengelompokkan yang benar, nilai pemain akan bertambah 15 poin. Selama waktu belum habis, maka dari state nilai bertambah akan terjadi transisi ke state huruf berjalan dengan epsilon (E) atau inputan string yang kosong.

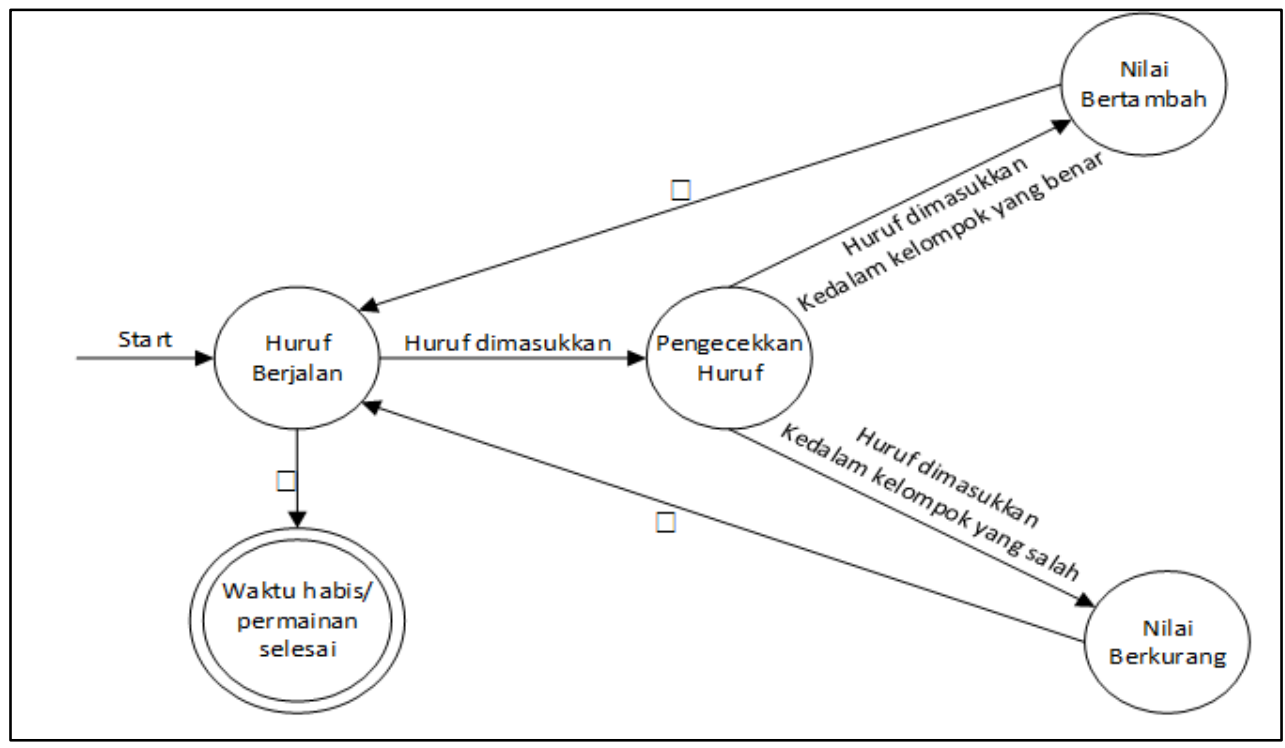

Gambar 10. Desain E-NFA

4. Nilai Berkurang: samahalnya bila pemain salah dalam pengelompokkan huruf, pemain akan diberi pengurangan nilai sebanyak 5 poin. Selama waktu belum habis, maka dari state nilai bertambah akan terjadi transisi ke state huruf berjalan dengan epsilon (E) atau inputan string yang kosong.

5. Waktu Habis/Permainan Selesai: selama jangka waktu yang telah ditentukan habis maka akan terjadi transisi dari state huruf berjalan ke state waktu habis/permainan selesai dengan epsilon $(\mathrm{E})$.

\section{Himpunan Input}

$\sum=\{\mathrm{E}$, Huruf dimasukkan, Kelompok yang benar, Kelompok yang salah $\}$

1. Epsilon (E): Diartikan sebagai transisi antar state tanpa inputan.

2. Huruf dimasukkan: Diartikan sebagai inputan ketika pemain mamilih salah satu huruf di state huruf berjalan.

3. Kelompok yang benar: Diartikan sebagai inputan ketika pemain menempatkan huruf kedalam kelompok yang benar.

4. Kelompok yang salah: Diartikan sebagai inputan ketika pemain menempatkan huruf kedalam kelompok yang salah.

\section{Fungsi Transisi}

$$
Q x(\Sigma \cup\{E\}) \rightarrow P(Q)
$$


Tabel 3. Transisi untuk Setiap Input

\begin{tabular}{cllll}
\hline $\begin{array}{c}\text { Input } \\
\text { State }\end{array}$ & i1 & \multicolumn{1}{c}{ i2 } & \multicolumn{1}{c}{ i3 } & \multicolumn{1}{c}{$\mathbf{E}$} \\
\hline $\mathbf{q 0}$ & $\mathrm{q} 1$ & - & - & $\mathrm{q} 4$ \\
$\mathbf{q 1}$ & - & $\mathrm{q} 2$ & $\mathrm{q} 3$ & - \\
$\mathbf{q} 2$ & - & - & - & $\mathrm{q} 0$ \\
$\mathbf{q 3}$ & - & - & - & $\mathrm{q} 0$ \\
$\mathbf{q 4}$ & - & - & - & - \\
\hline
\end{tabular}

Keterangan:

q0: Huruf Berjalan

q1: Pengecekkan huruf

q2: Nilai Bertambah

q3: Nilai Berkurang

q4: Waktu habis/permainan berakhir

i1: Huruf dimasukkan

i2: Kelompok yang benar

i3: Kelompok yang salah

E: epsilon

\section{Intial State dan Final State}

q0 : Huruf Berjalan

F : Waktu habis/permainan Berakhir

\section{SIMPULAN}

Hubungan dan transisi antar fungsional dalam aplikasi permainan lebih mudah didefinisikan dengan transisi antar state, sehingga dalam proses pembuatan desain aplikasi tidak terjadi kesalahan pendefinisian hubungan antar fungsional. Pada penelitian ini telah menunjukkan bagaimana pembuatan desain aplikasi permainnan "Game Tajwid" dengan pemodelan teori automata yaitu E-NFA sehingga akan menambah daya tarik dari player untuk belajar mengenali huruf hijaiyah. Penelitian selanjutnya dapat dikembangkan lagi dengan menggunakan jenis automata lainnya yang dapat menjadikan game ini lebih menarik dan efisien, misalnya dengan menambahkan kecerdasan buatan pada desain permainan ini.

\section{REFERENSI}

Ardiansyah, A., Hardi, N., \& Gata, W. (2020). Identifikasi dan Recovery File JPEG dengan Metode Signature-Based Carving dalam Model Automata. Komputika: Jurnal Sistem Komputer, 9(1), 75-83.

Arridho, F. Z. (2017). Game Edukasi Pengumpulan Sampah Organik dan Anorganik Menggunakan Finite State Machine. JATI (Jurnal Mahasiswa Teknik Informatika), 1(1), 498-505.

Fadhlurrahman, M., \& Capah, D. (2020). Aplikasi Penyewaan Lapangan Futsal Berbasis Web. Edumatic: Jurnal Pendidikan Informatika, 4(2), 30-39. https://doi.org/10.29408/edumatic.v4i2.2412

Hadi, A. P., Efendi, E., Danang, D., \& Wakid, N. (2017). Rancang Bangun Media Pembelajaran Tajwid Al Qur'an Berbasis Multimedia Interaktif. SEMNASTEKNOMEDIA ONLINE, 5(1), 4-6.

Handayani, K., Ismunandar, D., Putri, S. A., \& Gata, W. (2020). Penerapan Finite State Automata Pada Vending Machine Susu Kambing Etawa. MATICS, 12(2), 87-92.

Hutagaluh, E. J. (2017). Game Kebersihan Lingkungan Menggunakan Metode Finite State Machine. JATI (Jurnal Mahasiswa Teknik Informatika), 1(2), 222-228. 
Irawan, E., Siregar, S. P., Damanik, I. S., \& Saragih, I. S. (2020). Implementasi Algoritma KMedoids untuk Pengelompokkan Sebaran Mahasiswa Baru. Jurasik (Jurnal Riset Sistem Informasi Dan Teknik Informatika), 5(2), 275-281. https://doi.org/10.30645/jurasik.v5i2.213

Kharmoum, N., Retal, S., Ziti, S., \& Omary, F. (2019). A novel automatic transformation method from the business value model to the UML use case diagram. International Conference on Advanced Intelligent Systems for Sustainable Development, 38-50. Springer.

Komarudin, A., \& Yuniarti, R. (2016). Desain Dan Implementasi Non Playable Character Pada Permainan Edukasi Rantai Makanan Untuk Konsumen Tingkat 3 (Ular) Berteknologi Mobile Augmented Reality. Seminar Nasional Aptikom, 567-572. Mataram: APTIKOM.

Maarif, V., Nur, H. M., Rahayu, W., Informasi, S., Informatika, M., \& Informatika, T. (2018). Aplikasi pembelajaran ilmu tajwid berbasis android. Evolusi J. Sains Dan Manaj, 6(1), 91-100.

Muntohar, A. (2020). Sistem Informasi Data Klien Berbasis Java Pada Kantor Notaris dan PPAT Arif. Edumatic: Jurnal Pendidikan Informatika, 4(2), 58-67. https://doi.org/10.29408/edumatic.v4i2.2515

Mustofa, M., Sidiq, S., \& Rahmawati, E. (2018). Penerapan Finite State Machine Untuk Pengendalian Animasi Pada Video Game Rpg Nusantara Legacy. Jusikom: Jurnal Sistem Komputer Musirawas, 3(1), 1-10.

Rizal, R., Bustami, B., \& Azzahra, D. (2019). Pendeteksi Tajwid Idgham Mutajanisain Pada Citra Al-Qur'an Menggunakan Fuzzy Associative Memory (FAM). TECHSI-Jurnal Teknik Informatika, 11(3), 395-407.

Sabirin, F., Sulistiyarini, D., \& Zulkarnain, Z. (2020). Pengembangan Sistem Informasi Seminar dan Skripsi Mahasiswa. Edumatic: Jurnal Pendidikan Informatika, 4(1), 73-82.

Sahrul, F. K., Muhazabah, A., Prasetyo, A. D., Yunita, A., \& Zahra, N. L. (2018). Pengembangan Aplikasi Permainan 'Pilah Sampah'Menggunakan Pemodelan Finite State Machine. J. Teknol, 1(1), 38-46.

Saputra, S. A., Haryanto, H., \& Dolphina, E. (2019). Skenario Dinamis Menggunakan Finite State Machine pada Game Pengenalan Tempat dan Peristiwa Bersejarah. Jurnal Eksplora Informatika, 8(2), 112-121.

Setiaji, S. (2017). Kajian Efektivitas Kegiatan Belajar Mengajar dengan Game Edukasi Studi Kasus pada TK (Taman Kanak Kanak) Se Kecamatan Ciledug. Jurnal Pilar Nusa Mandiri, 13(2), 199-208.

Suprapto, D. D. A., Fauziah, F., Fitri, I., \& Hayati, N. (2020). Pengembangan Aplikasi Sistem Informasi Smart Register Online Berbasis Android Menggunakan Algoritma BruteForce. Edumatic: Jurnal Pendidikan Informatika, 4(1), 47-56.

Wirasbawa, N. D., Benedict, L., Santoso, B. G., Farhan, M. F., \& Kusnadi, A. (2019). Penerapan Konsep Non-Deterministic Finite Automata untuk Pembuatan Sereal Menggunakan Mesin Jual Otomatis dengan Dua Sistem Pembayaran. Simposium Nasional Ilmiah \& Call for Paper Unindra (Simponi), 440-448. Jakarta: Universitas Indraprasta PGRI. 